\title{
Inequalities in healthy life expectancy by Brazilian geographic regions: findings from the National Health Survey, 2013
}

\author{
Célia Landmann Szwarcwald*, Paulo Roberto Borges de Souza Júnior, Aline Pinto Marques, \\ Wanessa da Silva de Almeida and Dalia Elena Romero Montilla
}

\begin{abstract}
Background: The demographic shift and epidemiologic transition in Brazil have drawn attention to ways of measuring population health that complement studies of mortality. In this paper, we investigate regional differences in healthy life expectancy based on information from the National Health Survey (PNS), 2013.

Methods: In the survey, a three-stage cluster sampling (census tracts, households and individuals) with stratification of the primary sampling units and random selection in all stages was used to select 60,202 Brazilian adults (18 years and over). Healthy life expectancies (HLE) were estimated by Sullivan's method according to sex, age and geographic region, using poor self-rated health for defining unhealthy status. Logistic regression models were used to investigate socioeconomic and regional inequalities in poor self-rated health, after controlling by sex and age.

Results: Wide disparities by geographic region were found with the worst indicators in the North and Northeast regions, whether considering educational attainment, material deprivation, or health care utilization. Life expectancy at birth for women and men living in the richest regions was 5 years longer than for those living in the less wealthy regions. Modeling the variation across regions for poor self-rated health, statistically significant effects $(p<0.001)$ were found for the North and Northeast when compared to the Southeast, even after controlling for age, sex, diagnosis of at least one non-communicable chronic disease, and schooling or socioeconomic class. Marked regional inequalities in HLE were found, with the loss of healthy life much higher among residents of the poorest regions, especially among the elderly.

Conclusions: By combining data on self-rated health status and mortality in a single indicator, Healthy Life Expectancy, this study demonstrated the excess burden of poor health experienced by populations in the less wealthy regions of Brazil. To mitigate the effects of social exclusion, the development of strategies at the regional level is essential to provide health care to all persons in need, reduce risk exposures, support prevention policies for adoption of healthy behaviors. Such strategies should prioritize population groups that will experience the greatest impact from such interventions.
\end{abstract}

Keywords: Healthy life expectancy, Inequalities, Geographic regions, National health survey, Brazil

\section{Background}

Brazil is a middle-income country with large socioeconomic inequalities and extreme disparities in the distribution of income. These social inequalities may affect people's health status directly $[1,2]$ and also indirectly, by limiting their access to and utilization of health services [3-6]. Health inequalities found nationwide may therefore be considered a product of the poor living

\footnotetext{
* Correspondence: celia.szwarcwald@icict.fiocruz.br

Institute of Communication and Information Science and Technology in

Health, Oswaldo Cruz Foundation, Rio de Janeiro, Brazil
}

conditions experienced by a considerable fraction of the Brazilian population $[7,8]$.

Brazil is politically and geographically divided into five distinct regions (North, Northeast, Southeast, South and Center-West) with varied physical, demographic, and socioeconomic characteristics. Among the five Brazilian geographic regions, the North and the Northeast are the most deprived. The Southeast has greater economic importance and includes more than $40 \%$ of the Brazilian population, including the most populous states of São Paulo and Rio de Janeiro. The South has the smallest 
territorial area, comprises $14 \%$ of the total population, and is one of the two wealthiest regions. The CenterWest has an intermediate stage of development that has accelerated since Brazil's capital was moved to Brasilia in the 1960s. The concentration of poor socioeconomic conditions in the North and Northeast regions and inequalities in the distribution of health services and resources are reflected in a steep North-South gradient in many health indicators [9].

In Brazil, highlighting inequalities at the regional level proved to be especially important to promote actions and programs to decrease socioeconomic gaps. In the late 1990's, the Family Health Program was implemented as a national policy for primary care, giving priority to municipalities with the worst socioeconomic levels, especially those located in the North and Northeast [10]. The expansion of primary care in deprived areas showed important impacts: significant shrinkage in the historic regional gap in infant mortality rates [11]; important decline in unnecessary hospitalizations [12]; decrease in under-five mortality rates due to ill-defined causes and unattended deaths [13]; and reduction of mortality from heart and cerebrovascular diseases through cardiovascular disease prevention, care and follow-up [14].

Historically, national studies have focused on regional health inequalities emphasizing differences in mortality $[15,16]$. The demographic shift and the epidemiologic transition in Brazil have, however, drawn attention to other ways of measuring population health $[17,18]$. The growth in longevity has been accompanied by an increase in disability and in non-communicable chronic diseases that are changing the morbidity-mortality profile [19].

In this new scenario, different health indicators have been proposed to complement mortality by additionally accounting for morbidity and quality of life [20]. In national health surveys, self-rated health and self-reported diagnosis of chronic non-communicable diseases have been broadly used to establish differences in morbidity among population groups [21-23]. Health indicators that combine mortality data with morbidity or health status data have also been proposed for evaluating health care and prevention programs by placing greater emphasis on the quality of life in later years [24, 25].

Among the distinct health indicators that incorporate morbidity and mortality in a single measure, healthy life expectancy (HLE) obtained by Sullivan's method [26] has been the most frequently used due to its mathematical simplicity, the availability of required data, and the ease of interpreting results. This indicator is a population health measure that estimates the expected number of "healthy years" (years of life in good health) for persons at a given age. Definitions of "healthy" are usually based on self-rated health, long-term illness or disability, and functional or cognitive limitations [27].
In Brazil, healthy life expectancy has been estimated for the total adult population $[25,27,28]$ but regional differences in healthy longevity have been less well studied. Given the evidence indicating that differences in living conditions affect the regional pattern of morbidity and mortality in the country [29], this paper investigates regional inequalities in healthy life expectancy based on information from the National Health Survey, 2013.

\section{Methods}

As part of a project developed by the Ministry of Health $(\mathrm{MoH})$ aimed at assessing health system performance of Brazilian states and regions, the National Health Survey (Pesquisa Nacional de Saúde - PNS) was carried out in Brazil in partnership with the Brazilian Institute of Geography and Statistics (IBGE). The project was approved by the National Commission of Ethics in Research (CONEP) in June 2013 (No. 328.159).

The IBGE was responsible for the PNS sampling and fieldwork and the $\mathrm{MoH}$ was responsible for the PNS contents and financing.

\section{Sampling}

The National Health Survey (PNS) is a national household based survey. The surveyed population consisted of residents of private households in Brazil, excluding those located in special census tracts (military bases, lodges, camps, boats, prisons, asylums, orphanages, convents and hospitals). The sample used in the National Health Survey (PNS) is a subsample of the Master Sample of the Integrated Household Survey System (SIPD, IBGE), whose geographical scope comprises the census tracts of the Geographic Operating Base 2010 Population Census, except those with very small number of households and special sectors [30].

A three-stage cluster sampling (census tracts, households and individuals) was used with stratification of the primary sampling units (PSUs) and random selection in each stratum. Census tracts or set of sectors compose the primary sampling units (PSUs), households are the units of the second stage and residents aged 18 or older define the third-stage units. As part of the Integrated Household Survey System, the PSUs were obtained from the Master Sample, using the same PSU stratification.

In each PSU, from 10 to 14 households were selected using a simple random sample from the National Register of Addresses for Statistical Purposes (CNEFE, IBGE). In each selected household, an adult (18 years old and over) was selected with equal probability to answer the questionnaire through a face-to-face interview [30].

\section{Fieldwork}

Interviewers, supervisors and coordinators of the IBGE carried out the PNS fieldwork. Training materials were 
prepared in partnership with the $\mathrm{MoH}$. Coordinators and supervisors were trained in person and then they trained all field staff to conduct interviews using PDAs (Personal Digital Assistants) and to perform anthropometric and blood pressure measurements. A consortium of private laboratories carried out the collection and laboratory tests on the biological samples (blood and urine) [31].

The PNS fieldwork was carried out from August, 2013 to February, 2014 with 6,069 selected census tracts and 81,254 visited households. From these, 69,994 households were occupied, 64,348 household interviews were conducted, and 60,202 individual interviews completed. Response rates by state are available in a previous publication [32].

\section{Measurement instrument}

The PNS questionnaire is divided into three parts: characteristics of the household (water and sanitation, electricity, household assets); demographic and health information on all household residents (sociodemographic characteristics, access and utilization of health care, private health insurance coverage for all household members); and the individual questionnaire, which includes modules on selfperception of health, accidents and violence, life styles, non-communicable chronic diseases, women's health, oral health, health care use, and assessment of the quality of care received. The entire questionnaire is available at the PNS site (www.pns.fiocruz.br). Only one household member (key informant) answers the first and second parts for all household residents. The individual questionnaire is answered by a resident of 18 years and older, selected with equal probability among all adult household residents as described above.

\section{Main indicators}

In this paper, to show socioeconomic differences by Brazil's five macro-geographic regions, we used indicators of educational attainment, health care access and utilization, and coverage by a private health plan. We calculated an index based on the number of household assets, degree of education of the household head and presence of monthly paid housekeeper, using a standard Brazilian classification scheme for social class: (A/B) upper class; C (middle class); and lower class (D/E), adapting the approach of the Brazilian Association of Survey Firms [33].

The standard method for assessing social class in Brazil combines the household asset index, calculated by a sum of points attributed to the number of households goods with larger weights attributed to certain highvalue items, and the level of instruction of the household head, with higher point attributed to greater educational attainment. The sum of household points is then aggregated in intervals to define social class categories: D/E (0-13 points); C (14-23 points); A/B (24-50 points).

Healthy life expectancies were estimated by Sullivan's method [26] according to sex, age and geographic region. The approach is an adaptation of the traditional life table method using two independent measures of health: the specific rate of being healthy by age group and the mortality component given by age-specific life expectancy provided by the IBGE [34]. The method consists of removing the proportion of time lived in poor health from the total expected lifespan of a given cohort [27]:

$$
\mathrm{HLE}=\frac{1}{\mathrm{l}_{\mathrm{x}}} \sum_{\mathrm{x}}^{\mathrm{w}}\left(1{ }^{-}{ }_{n} \pi_{\mathrm{x}}\right)_{n} \mathrm{~L}_{x}
$$

where $l_{x}$ is the number of survivors at the exact age $x ;{ }_{n} \pi_{x}$ represents the prevalence of a determined state of health (poor self-rated health) among individuals with ages in the interval $(x, x+n) ;{ }_{n} L_{x}$ is the total number of years lived by a cohort in the age group $(x, x+n)$; and $w$ represents the largest age category.

To establish the "unhealthy state" we used self-rated health based on the following PNS question: "In general, how would you rate your health? "with five possible answers (very good, good, moderate, bad, very bad). The first three options were aggregated to define "good health" and the two last categories to define "poor selfrated health". The age specific rate of being unhealthy was estimated by the proportion of people reporting poor self-rated health in each 5 -year age group.

\section{Data analysis}

Logistic regression models were used to investigate socioeconomic and regional inequalities in poor self-rated health, after controlling by sex and age. The effects of geographic regions (considered as dummy variables) were also adjusted by a binary variable representing diagnosis of at least one non-communicable chronic disease.

As the PNS design used stratification of census tracts and multiple stage cluster selection, the complex sample design was considered in the statistical analysis.

\section{Results}

Inequalities by geographic regions

Table 1 shows the distribution of people aged 20 years and over by geographic region according to socioeconomic characteristics. Wide disparities were found by region with the worst indicators consistently found in the North and Northeast. In relation to educational attainment, while in the Southeast over $50 \%$ completed secondary school, in the Northeast, this proportion is lower than $40 \%$. In the Northeast, 
Table 1 Socioeconomic and health indicators among adults aged 20 years and ver $^{\mathrm{c}}$ by Brazilian regions, 2013

\begin{tabular}{|c|c|c|c|c|c|c|c|}
\hline \multirow[t]{2}{*}{ Indicators } & \multicolumn{5}{|c|}{ Geographic Region } & \multirow[t]{2}{*}{ Brazil } & \multirow[t]{2}{*}{$p$-value ${ }^{*}$} \\
\hline & North & Northeast & Southeast & South & Center-West & & \\
\hline Schooling & & & & & & & $p<0.001$ \\
\hline Illiterate & 19.4 & 23.0 & 9.9 & 9.7 & 12.4 & 14.2 & \\
\hline Incomplete elementary school & 23.4 & 26.4 & 24.8 & 29.3 & 25.3 & 25.8 & \\
\hline Incomplete secondary school & 15.5 & 12.9 & 14.4 & 15.5 & 14.9 & 14.3 & \\
\hline Complete secondary school & 41.7 & 37.7 & 50.9 & 45.5 & 47.4 & 45.7 & \\
\hline Socioeconomic class & & & & & & & $p<0.001$ \\
\hline$A / B$ & 16.8 & 18.6 & 40.2 & 42.8 & 34.0 & 32.7 & \\
\hline C & 42.3 & 38.9 & 44.7 & 43.6 & 44.5 & 42.8 & \\
\hline $\mathrm{D} / \mathrm{E}$ & 40.9 & 42.5 & 15.1 & 13.6 & 21.5 & 24.5 & \\
\hline$\%$ Adults living in rural areas & 21.7 & 23.8 & 6.9 & 15.0 & 8.9 & 13.8 & $p<0.001$ \\
\hline $\begin{array}{l}\% \text { Adults who consulted a doctor in } \\
\text { the last } 12 \text { months }\end{array}$ & 66.4 & 69.7 & 79.5 & 78.6 & 73.8 & 75.4 & $p<0.001$ \\
\hline Coverage (\%) of private health plan & 12.6 & 14.7 & 34.5 & 31.4 & 28.0 & 26.7 & $p<0.001$ \\
\hline Diagnosis of at least one NCD & 39.0 & 44.4 & 47.4 & 53.2 & 44.8 & 46.7 & $p<0.001$ \\
\hline Life Expectancy at birth (years) ${ }^{a}$ & & & & & & & - \\
\hline M & 68.2 & 68.1 & 73.3 & 73.5 & 71.2 & 71.3 & \\
\hline $\mathrm{F}$ & 75.3 & 76.5 & 79.5 & 80.3 & 77.9 & 78.1 & \\
\hline $\mathrm{T}$ & 71.5 & 72.2 & 76.6 & 76.9 & 74.4 & 74.8 & \\
\hline $\begin{array}{l}\text { Number of doctors per } 1000 \\
\text { population }^{\text {b }}\end{array}$ & 0.9 & 1.09 & 2.51 & 2.06 & 1.76 & 1.86 & - \\
\hline \multicolumn{8}{|l|}{ Poor self-rated health } \\
\hline M & 5.8 & 7.0 & 3.5 & 4.0 & 5.0 & 4.8 & $p<0.001$ \\
\hline $\mathrm{F}$ & 7.6 & 9.4 & 5.2 & 6.5 & 6.0 & 6.7 & $p<0.001$ \\
\hline T & 6.8 & 8.3 & 4.4 & 5.3 & 5.5 & 5.8 & $p<0.001$ \\
\hline
\end{tabular}

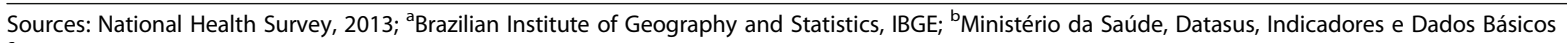
'Weighted Sample size 57,287

" $p$-value of the chi-square test for comparison between geographic region distributions

more than one fifth of adults is illiterate. As to socioeconomic class, in the North, more than $40 \%$ of the adult population is classified in the lowest classes $(\mathrm{D} / \mathrm{E})$ and less than $20 \%$ in the upper classes A and B. In contrast, in the South and Southeast, $40 \%$ or more belongs to class A/B and less than $20 \%$ in class $\mathrm{D} / \mathrm{E}$. Coverage of private health plans varied from $12.6 \%$ (North) to $34.5 \%$ (Southeast). Differences in the distributions by macro geographic regions were all statistically significant $(p<0.001)$.

Differences in health care utilization are also pronounced. The proportion of adults who consulted a doctor in the last 12 months ranged from $66.4 \%$ in the North to $79.5 \%$ in the Southeast. Great inequalities in the indicator of health resource supply are also found: in the Southeast, the number of doctors per 1000 inhabitants is almost three times higher than in the North. Barriers to access for diagnosis of long-term illness result in unequal prevalence rates, with the lowest proportion (39\%) of diagnoses of at least one non-communicable chronic disease found in the North (Table 1).
Life expectancy by geographic region also varied directly with socioeconomic development: the wealthier the region, the greater the longevity. The North and the Northeast have the shortest life expectancy at birth for both men and women. Life expectancy at birth of women and men living in the richest regions was 5 years longer than that of those living in the less developed regions (Table 1).

The proportion of adults with poor self-rated health by sex and geographic region is also shown in Table 1 . Marked regional inequalities were found with the richest regions having the smallest proportions of poor selfrated health for both sexes. The proportion of poor selfrated health in Brazil was $5.8 \%$ and ranged from $4.4 \%$ in the Southeast to $8.3 \%$ in the Northeast. Comparing the proportions by sex, females have greater proportions of poor self-rated health in all regions.

\section{Inequalities in self-rated health}

Results of the logistic regression model of poor selfrated heath are presented in Table 2. The odds-ratio 
Table 2 Results of logistic regression models having poor self-rated health as the response variable. Brazil, 2013

\begin{tabular}{lllll}
\hline Variables & & OR & $95 \% \mathrm{Cl}$ & $p$-value \\
\hline Sex & $\mathrm{F}$ & 1.41 & $1.26-1.58$ & $p<0.001$ \\
Age group & $\mathrm{M}$ & 1.00 & - & - \\
& $20-29$ & 1.00 & - & - \\
& $30-39$ & 1.80 & $1.36-2.37$ & $p<0.001$ \\
& $40-49$ & 3.64 & $2.85-4.64$ & $p<0.001$ \\
& 50-59 & 5.54 & $4.37-7.02$ & $p<0.001$ \\
& $60-69$ & 6.99 & $5.49-8.92$ & $p<0.001$ \\
& 70+ & 9.21 & $7.15-11.87$ & $p<0.001$ \\
& North & 2.01 & $1.64-2.48$ & $p<0.001$ \\
& Northeast & 2.18 & $1.87-2.55$ & $p<0.001$ \\
& Southeast & 1.00 & - & - \\
& South & 1.26 & $1.04-1.54$ & 0.019 \\
& Center-West & 1.34 & $1.11-1.61$ & 0.002 \\
\hline
\end{tabular}

(OR) for females is $1.41(p<0.001)$ when compared to males and increases with age. The chance of having poor self-rated health is nine times higher for persons aged 70 years and over as compared to young adults aged 20 to 29 years. Statistically significant effects $(p<0.001)$ were found for all four regions when compared to the Southeast, with higher effects corresponding to the Northeast and to the North (Table 2).

Modeling the variation among regions for poor selfrated health after controlling for educational level, age group, and sex (Table 3 Model 1A), the effects of the North and Northeast remain statistically significant $(p<0.001)$, the effect of the Center-West decreases but is still significant $(p<0.02)$, but the effect corresponding to the South is no longer statistically significant. After including the dummy variable representing diagnosis of at least one non-communicable chronic disease in the previous model (Model 2A), the largest effect corresponded to this variable, but no changes in the significance of the region effects were found. When we replace schooling with socioeconomic class in the two logistic regression models, we observe a more pronounced effect of household assets than educational attainment (models 2A and 2B). However, the effects of the North and Northeast persist $(p<0.001)$ when compared to the Southeast in both models.

\section{Healthy life expectancy estimates}

The estimated life expectancies, years lived in poor health, and healthy life expectancies by sex and regions, at 20, 40 and 60 years of age are shown in Table 4. Regional differences in healthy life expectancy are higher than the differences in life expectancy for all ages. At twenty years old, HLE estimates in the South and Southeast are 6.2 years higher than in the North and Northeast, for both women and men. At 40 years, the gap decreases to 5.3 years, approximately, and at 60 , to 3.5 years.

\section{Discussion}

This is the first study to show inequalities in healthy life expectancy in Brazil by geographic region. Overall, the findings were consistent with previous studies: although women live longer than men, they live relatively fewer years in good health and the percentage of years of healthy life lost increases with age [27, 35]. As to estimates by geographic region, beyond the variation in life expectancy at birth, marked regional inequalities were found in healthy longevity between the least and most developed macro regions of Brazil.

To calculate HLE, we used Sullivan's method and adopted poor self-rated health as the definition for the unhealthy state. Firstly, because a broader definition of health transcends the absence of death, disease and disability and incorporates concepts of well-being and quality of life [36]. Different from a biomedical assessment of health status, which identifies disease by a set of signs, symptoms and laboratory data, self-perception of health is subjective, combining physical and emotional components of well-being [37]. Secondly, in the context of comparing HLE regional estimates, unhealthy state definitions based on diagnosed morbidity do not work well as they depend on access to diagnosis, admittedly uneven by region and area of residence (urban/rural) $[9,38]$. A limitation of this study, however, is that data on functional limitations of daily activities are not available for the total PNS sample, only for persons aged 60 years and over, and so could not be used as an estimator of health status.

With the current growth in longevity experienced by populations throughout the world, the proportion of years not lived in full health will likely increase, and measures of unhealthy state are becoming increasingly important. Different techniques have been proposed to refine the simple binary measures of health states, like quality-adjusted life years [39] or the Canadian composite index of wellbeing based on eight domains of health [40]. Nevertheless, the recurrent utilization of self-rated health comes from its validity, established by its association with more objective measures of health disorders [23] and its potential use to identify already disabled persons [41].

A previous study in Brazil based on the World Health Survey (WHS), 2003 compared three measures of unhealthy states: poor self-rated health; presence of a longterm disease or disability that limits daily activities; and a principal component score based on severity of functional limitations resulting or not from long-term illness. Although more complex, the two approaches that 
Table 3 Logistic regression results: geographic region effects on poor self-rated health. Brazil, 2013

\begin{tabular}{|c|c|c|c|c|c|c|c|c|c|c|c|c|c|}
\hline \multirow{2}{*}{ Variables } & & \multicolumn{3}{|c|}{ Model 1A } & \multicolumn{3}{|c|}{ Model 1B } & \multicolumn{3}{|c|}{ Model 2A } & \multicolumn{3}{|c|}{ Model 2B } \\
\hline & & $\overline{O^{a}}$ & $95 \% \mathrm{Cl}$ & $p$-value & $\overline{O R^{b}}$ & $95 \% \mathrm{Cl}$ & $p$-value & $\overline{\mathrm{OR}^{c}}$ & $95 \% \mathrm{Cl}$ & $p$-value & $\overline{\mathrm{OR}^{d}}$ & $95 \% \mathrm{Cl}$ & $p$-value \\
\hline \multirow[t]{2}{*}{ Sex } & $\mathrm{F}$ & 1.47 & $1.31-1.65$ & 0.000 & 1.42 & $1.26-1.59$ & 0.000 & 1.28 & $1.14-1.44$ & 0.000 & 1.24 & $1.10-1.40$ & $p<0.001$ \\
\hline & M & 1.00 & - & - & 1.00 & - & - & 1.00 & - & - & 1.00 & - & - \\
\hline \multirow[t]{6}{*}{ Age group } & $20-29$ & 1.00 & - & - & 1.00 & - & - & 1.00 & - & - & 1.00 & - & - \\
\hline & 30-39 & 1.54 & $1.17-2.02$ & 0.002 & 1.93 & $1.46-2.55$ & 0.000 & 1.26 & $0.95-1.67$ & 0.113 & 1.60 & $1.20-2.13$ & $p<0.001$ \\
\hline & $40-49$ & 2.62 & $2.05-3.35$ & 0.000 & 3.84 & $3.01-4.91$ & 0.000 & 1.74 & $1.36-2.23$ & 0.000 & 2.56 & $1.99-3.28$ & $p<0.001$ \\
\hline & 50-59 & 3.58 & $2.83-4.54$ & 0.000 & 5.57 & $4.39-7.06$ & 0.000 & 2.00 & $1.56-2.56$ & 0.000 & 3.08 & 2.39-3.96 & $p<0.001$ \\
\hline & $60-69$ & 3.91 & $3.05-5.01$ & 0.000 & 6.38 & $5.00-8.14$ & 0.000 & 1.94 & $1.50-2.52$ & 0.000 & 3.13 & $2.42-4.04$ & $p<0.001$ \\
\hline & $70+$ & 4.51 & $3.46-5.86$ & 0.000 & 7.59 & $5.88-9.79$ & 0.000 & 2.15 & $1.64-2.82$ & 0.000 & 3.55 & $2.73-4.63$ & $p<0.001$ \\
\hline \multirow[t]{3}{*}{ Schooling } & Incomplete Elementary & 3.95 & $3.36-4.65$ & 0.000 & - & - & - & 3.83 & $3.26-4.51$ & 0.000 & - & - & - \\
\hline & Incomplete Secondary & 1.74 & $1.41-2.14$ & 0.000 & - & - & - & 1.67 & $1.35-2.06$ & 0.000 & - & - & - \\
\hline & Complete Secondary & 1.00 & - & - & - & - & - & 1.00 & - & - & - & - & - \\
\hline \multirow[t]{5}{*}{ Region } & North & 1.73 & $1.40-2.13$ & 0.000 & 1.42 & $1.15-1.76$ & 0.001 & 1.87 & $1.51-2.31$ & 0.000 & 1.51 & $1.22-1.88$ & $p<0.001$ \\
\hline & Northeast & 1.82 & $1.55-2.13$ & 0.000 & 1.56 & $1.33-1.84$ & 0.000 & 1.90 & $1.62-2.22$ & 0.000 & 1.60 & $1.36-1.87$ & $p<0.001$ \\
\hline & Southeast & 1.00 & - & - & 1.00 & - & - & 1.00 & - & - & 1.00 & - & - \\
\hline & South & 1.18 & $0.97-1.42$ & 0.100 & 1.26 & $1.04-1,52$ & 0.018 & 1.08 & $0.90-1.31$ & 0.412 & 1.14 & $0.95-1.38$ & 0.162 \\
\hline & Center-West & 1.25 & $1.04-1.50$ & 0.018 & 1.19 & $0.99-1.43$ & 0.061 & 1.26 & $1.05-1.52$ & 0.013 & 1.18 & $0.98-1.42$ & 0.081 \\
\hline \multirow[t]{3}{*}{ SE class } & $\mathrm{D} / \mathrm{E}$ & - & - & - & 5.14 & $4.18-6.33$ & 0.000 & - & - & - & 5.30 & $4.32-6.49$ & $p<0.001$ \\
\hline & C & - & - & - & 2.97 & $2.44-3.62$ & 0.000 & - & - & - & 2.93 & $2.41-3.57$ & $p<0.001$ \\
\hline & $A / B$ & - & - & - & 1.00 & - & - & - & - & - & 1.00 & - & - \\
\hline \multirow[t]{2}{*}{ At least one NCD } & Yes & - & - & - & - & - & - & 5.08 & $4.29-6.01$ & 0.000 & 5.27 & $4.45-6.23$ & $p<0.001$ \\
\hline & No & - & - & - & - & - & - & 1.00 & - & - & 1.00 & - & - \\
\hline
\end{tabular}

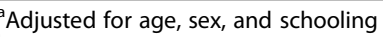

${ }^{b}$ Adjusted for age, sex, and socioeconomic (SE) class

${ }^{\mathrm{c}}$ Adjusted for age, sex, schooling, and diagnosis of at least one non-communicable chronic disease (NCD)

${ }^{\mathrm{d}}$ Adjusted for age, sex, socioeconomic class, and diagnosis of at least one non-communicable chronic disease (NCD)

included presence of functional limitations produced very similar results to the estimate based on self-rated health, especially in the elderly [27].

As the WHS sample does not allow us to make statistical inferences by geographic region [42], we compared the PNS (2013) and WHS (2003) results at the national level. Life expectancy at 20 years old increased more than 2 years and at 60 years old, more than one year. However, the largest increase was found in healthy life expectancy. Ten years later, considering exactly the same question for self-rated health, the number of lost healthy years decreased from 6.9 to 4.2 at 20 years old, and from 4.8 to 2.8 at 60 years old. As has been shown before, Brazilians are living longer and feeling better [25].

Given the significant growth of non-communicable chronic diseases and disabling disorders in the Brazilian population [19], the HLE increase is apparently paradoxical. A likely explanation is the improvement of quality of life of the Brazilian population in terms of socioeconomic conditions and access to health care [29, 43, 44], in the so called virtuous circle generated by the large social investments in the country. Recent national studies have also shown the influence of better-quality life conditions, expansion of primary health care, and the impact of the income inequality reduction on morbidity and mortality indicators [45-47].

In respect to regional variation, our results showed pronounced inequalities in life expectancy, confirming previous mortality studies [48]. Significant regional differences in poor self-rated health were also found. Comparative statistical analysis between the North and Northeast regions to the Southeast showed significant effects, even after controlling for age, sex, diagnosis of at least one non-communicable chronic disease, and schooling or socioeconomic class. These results indicate that regional differences in health self-perception reflect socio-structural influences, which go beyond the concentration of poverty and educational attainment [49], as well as factors that determine different experiences of illness as social consequences of living in disadvantaged areas [37].

As to regional inequality in healthy years, the results suggest that HLE is a more sensitive indicator than life expectancy. At age 60, the loss of healthy years is twice 
Table 4 Life expectancy (LE), healthy life expectancy (HLE), and lost healthy years (LHY) by age, sex, and Brazilian region, 2013

\begin{tabular}{|c|c|c|c|c|c|c|c|c|c|}
\hline \multirow[t]{2}{*}{ Region } & \multicolumn{3}{|l|}{ M } & \multicolumn{3}{|l|}{$\mathrm{F}$} & \multicolumn{3}{|l|}{$\mathrm{T}$} \\
\hline & $\mathrm{LE}$ & HLE & LHY & LE & HLE & LHY & $\mathrm{LE}$ & HLE & LHY \\
\hline \multicolumn{10}{|c|}{ At 20 years of age } \\
\hline North & 50.9 & 46.3 & 4.6 & 57.3 & 50.9 & 6.4 & 53.9 & 48.5 & 5.4 \\
\hline Northeast & 50.7 & 46.3 & 4.4 & 58.4 & 51.3 & 7.1 & 54.5 & 48.7 & 5.8 \\
\hline Southeast & 54.8 & 52.5 & 2.4 & 61.1 & 57.2 & 3.9 & 58.0 & 54.9 & 3.2 \\
\hline South & 55.0 & 52.1 & 2.9 & 61.4 & 56.1 & 5.4 & 58.2 & 54.1 & 4.2 \\
\hline Center-West & 53.4 & 49.7 & 3.6 & 59.6 & 54.6 & 4.9 & 56.4 & 52.1 & 4.3 \\
\hline Brazil & 53.3 & 49.5 & 3.8 & 60.1 & 54.9 & 5.2 & 56.7 & 52.4 & 4.2 \\
\hline \multicolumn{10}{|c|}{ At 40 years of age } \\
\hline North & 34.3 & 29.7 & 4.6 & 38.6 & 32.8 & 5.9 & 36.3 & 31.2 & 5.1 \\
\hline Northeast & 34.1 & 30.0 & 4.1 & 39.5 & 33.0 & 6.5 & 36.9 & 31.5 & 5.3 \\
\hline Southeast & 36.7 & 34.6 & 2.1 & 41.8 & 38.3 & 3.5 & 39.3 & 36.5 & 2.8 \\
\hline South & 36.9 & 34.0 & 2.9 & 42.1 & 37.2 & 4.9 & 39.6 & 35.6 & 3.9 \\
\hline Center-West & 53.4 & 49.7 & 3.6 & 40.5 & 35.9 & 4.6 & 38.2 & 34.1 & 4.1 \\
\hline Brazil & 35.8 & 32.3 & 3.5 & 41.0 & 36.3 & 4.7 & 38.5 & 34.6 & 3.9 \\
\hline \multicolumn{10}{|c|}{ At 60 years of age } \\
\hline North & 18.7 & 15.3 & 3.4 & 21.6 & 18.0 & 3.6 & 20.1 & 16.7 & 3.4 \\
\hline Northeast & 18.9 & 16.1 & 2.7 & 22.4 & 17.9 & 4.4 & 20.7 & 17.0 & 3.7 \\
\hline Southeast & 20.4 & 18.8 & 1.7 & 24.1 & 21.6 & 2.4 & 22.4 & 20.3 & 2.1 \\
\hline South & 20.4 & 18.2 & 2.2 & 24.2 & 20.6 & 3.5 & 22.4 & 19.5 & 2.9 \\
\hline Center-West & 19.8 & 16.9 & 2.9 & 22.8 & 19.6 & 3.3 & 21.3 & 18.2 & 3.1 \\
\hline Brazil & 19.9 & 17.3 & 2.5 & 23.4 & 20.2 & 3.2 & 21.7 & 18.9 & 2.8 \\
\hline
\end{tabular}

Sources: Life expectancy provided by IBGE [31]; HLE derived from Sullivan's method using poor self-assessment of health to establish unhealthy state based on PNS data

$M$ male, $F$ female, $T$ total

as high in the North as in the Southeast. These findings are in accordance with previous national and international studies. A study in the city of Rio de Janeiro showed huge HLE differences in the elderly, by comparing socioeconomic strata within the city [50]. Similar analyses in South Korea showed the importance of considering communitylevel socioeconomic conditions as key correlates of survival [49]. In the United States, large HLE inequalities have also been reported by geographic region [51].

Evidence of the effects of socioeconomic inequalities on healthy longevity are increasingly available, as well. Results are invariably unfavourable to the disadvantaged groups [52-54]. In England, a recent study combined survey data on health-related quality of life with mortality data and found a difference of approximately 11 lost years of quality of life between the most and least healthy quintile groups [55]. A study in European countries showed large and increasing inequalities in healthy life expectancy at age 50 from 2005 to 2010, partly explained by worsening of material deprivation and longterm unemployment [56].
By showing that not only mortality indicators are associated with living conditions, but that regional inequalities are even more pronounced when well-being is taken into consideration, this study renews attention to the need for promoting actions and programs to decrease socio-spatial gaps. The inclusion of health selfassessment in addition to the mortality component in a single health indicator demonstrated the excess burden of poor health experienced by populations in the less developed regions. To mitigate the effects of social exclusion, the development of strategies at the regional level is essential not only to provide health care to all persons in need, but also to reduce risk exposures and to support prevention policies for adoption of healthy behaviors, prioritizing the disadvantaged population groups that will have the greater impact of interventions.

\section{Conclusions}

The findings suggest that wellness should be taken into account while monitoring geographic health inequalities, especially among elderly, and point to the adoption of HLE as an outcome measure at the national, regional, state, and community levels to compare the effectiveness of health interventions and evaluate disparities. In this context, the results presented here can be used as a baseline to monitor targets in healthy life expectancy and in regional health inequalities.

\section{Abbreviations}

PNS: National health survey; HLE: Healthy life expectancies; MoH: Ministry of health; IBGE: Brazilian Institute of Geography and Statistics; CONEP: National Commission of Ethics in Research; SIPD: Master sample of the integrated household survey system; PSU: Primary sampling unit; CNEFE: National register of addresses for statistical purposes; PDA: Personal digital assistants; OR: Odds-ratio; WHS: World Health Survey

\section{Acknowledgements}

Not applicable.

Funding

Ministry of Health.

\section{Availability of data and materials}

The dataset analyzed during the current study is publicly available (http:// www.ibge.gov.br/home/estatistica/populacao/pns/2013/default.shtm).

Authors' contributions

CLS, PRBSJ and DERM participated in all stages of preparation of the article. APM and WSA participated in the data analysis and interpretation of results. All authors read and approved the final manuscript.

Competing interests

The authors declare that they have no competing interests.

Consent for publication

Not applicable.

Ethics approval and consent to participate

The project was approved by the National Commission of Ethics in Research (CONEP) in June 2013 (No. 328.159). 
Received: 25 April 2016 Accepted: 2 September 2016

Published online: 17 November 2016

\section{References}

1. Rasella D, Aquino R, Barreto ML. Impact of income inequality on life expectancy in a highly unequal developing country: the case of Brazil. J Epidemiol Community Health. 2013;67(8):661-6. doi:10.1136/jech-2012-201426.

2. Barros MB, Francisco PM, Zanchetta LM, César CL. Trends in social and demographic inequalities in the prevalence of chronic diseases in Brazil. PNAD: 2003-2008. Cien Saude Colet. 2011;16(9):3755-68. doi:10.1590/S141381232011001000012

3. Chor D, Ribeiro ALP, Carvalho MS, Duncan BB, Lotufo PA, Nobre AA, et al. Prevalence, Awareness, Treatment and Influence of Socioeconomic Variables on Control of High Blood Pressure: Results of the ELSA-Brasil Study. PLoS One. 2015:10(6), e0127382. doi:10.1371/journal.pone.0127382.

4. Nunes BP, Thumé E, Tomasi E, Duro SM, Facchini LA. Socioeconomic inequalities in the access to and quality of health care services. Rev Saude Publica. 2014;48(6):968-76. doi:10.1590/S0034-8910.2014048005388.

5. Miquilin IO, Marín-León L, Monteiro MI, Corrêa Filho HR. Inequalities in health services access and use among formal, informal, and unemployed workers, based on data from the Brazilian National Household Sample Survey, 2008. Cad Saude Publica. 2013;29(7):1392-406. doi:10.1590/S0102$311 \times 2013000700013$

6. Louvison MC, Lebrão ML, Duarte YA, Santos JL, Malik AM, Almeida ES. Inequalities in access to health care services and utilization for the elderly in São Paulo, Brazil. Rev Saude Publica. 2008:42(4):733-40. doi:10.1590/S003489102008000400021

7. Carvalho RA, Santos VS, Melo CM, Gurgel RQ, Oliveira CC. Inequalities in health: living conditions and infant mortality in Northeastern Brazil. Rev Saude Publica. 2015;49:5. doi:10.1590/S0034-8910.2015049004794.

8. Alves H, Escorel S. Social exclusion and health inequity: a case study based on a cash distribution program (Bolsa Família) in Brazil. Rev Panam Salud Publica. 2013:34(6):429-36.

9. Viacava F, Bellido JG. Health, access to services and sources of payment, according to household surveys. Cien Saude Colet. 2016;21(2):351-70. doi:10.1590/1413-81232015212.19422015.

10. Paim J, Travassos C, Almeida C, Bahia L, Macinko J. The Brazilian health system: history, advances, and challenges. Lancet. 2011;377(9779):1778-97. doi:10.1016/S0140-6736(11)60054-8.

11. Szwarcwald CL, Frias PG, Júnior PR, Almeida WS, Neto OL. Correction of vital statistics based on a proactive search of deaths and live births: evidence from a study of the North and Northeast regions of Brazil. Popul Health Metr. 2014;12:16. doi:10.1186/1478-7954-12-16.

12. Macinko J, Oliveira VB, Turci MA, Guanais FC, Bonolo PF, Lima-Costa MF. The influence of primary care and hospital supply on ambulatory care-sensitive hospitalizations among adults in Brazil, 1999-2007. Am J Public Health. 2011;101(10):1963-70. doi:10.2105/AJPH.2010.198887.

13. Rasella D, Aquino R, Barreto ML. Impact of the Family Health Program on the quality of vital information and reduction of child unattended deaths in Brazil: an ecological longitudinal study. BMC Public Health. 2010;10:380. doi:10.1186/1471-2458-10-380.

14. Rasella D, Harhay MO, Pamponet ML, Aquino R, Barreto ML. Impact of primary healthcare on mortality from heart and cerebrovascular diseases in Brazil: a nationwide analysis of longitudinal data. BMJ. 2014;349:g4014. doi:10.1136/bmj.g4014

15. Barufi AM, Haddad E, Paez A. Infant mortality in Brazil, 1980-2000: a spatial panel data analysis. BMC Public Health. 2012;12:181. doi:10.1186/1471-2458-12-181.

16. Duarte EC, Schneider MC, Paes-Sousa R, Silva JB, Castillo-Salgado C. Life expectancy at birth and mortality in Brazil, 1999: exploratory analysis of regional differences. Rev Panam Salud Publica. 2002;12(6):436-44. doi:10. 1590/S1020-49892002001200009.

17. Theme Filha MM, Szwarcwald CL, Souza Junior PR. Measurements of reported morbidity and interrelationships with health dimensions. Rev Saude Publica. 2008;42(1):73-81. doi:10.1590/S0034-89102008000100010.

18. Moura EC, Pacheco-Santos LM, Peters LR, Serruya SJ, Guimarães R. Research on chronic noncommunicable diseases in Brazil: meeting the challenges of epidemiologic transition. Rev Panam Salud Publica. 2012;31(3):240-5. doi:10. 1590/S1020-49892012000300009.

19. Schmidt MI, Duncan BB, Azevedo e Silva G, Menezes AM, Monteiro CA, Barreto SM, et al. Chronic non-communicable diseases in Brazil: burden and current challenges. Lancet. 2011;377(9781):1949-61. doi:10.1016/S0140-6736(11)60135-9.
20. Leite IC, Valente JG, Schramm JM, Daumas RP, Rodrigues RN, Santos MF, et al. Burden of disease in Brazil and its regions, 2008. Cad Saude Publica. 2015;31(7):1551-64. doi:10.1590/0102-311X00111614.

21. Meireles AL, Xavier CC, Andrade AC, Friche AA, Proietti FA, Caiaffa WT. Selfrated health in urban adults, perceptions of the physical and social environment, and reported comorbidities: The BH Health Study. Cad Saude Publica. 2015;31(1 Suppl):120-35. doi:10.1590/0102-311X00076114.

22. Höfelmann DA, Roux AVD, Antunes JL, Peres MA. Association of perceived neighborhood problems and census tract income with poor self-rated health in adults: a multilevel approach. Cad Saude Publica. 2015;31(1 Suppl): 79-91. doi:10.1590/0102-311X00210913.

23. Theme Filha MM, Souza Junior PR, Damacena GN, Szwarcwald CL. Prevalence of chronic non-communicable diseases and association with self-rated health: National Health Survey, 2013. Rev Bras Epidemiol. 2015; 18(2 Suppl):83-96. doi:10.1590/1980-5497201500060008.

24. Campolina AG, Adami F, Santos JL, Lebrão ML. The health transition and changes in healthy life expectancy in the elderly population: possible impacts of chronic disease prevention. Cad Saude Publica. 2013;29(6):1217-29. doi:10. 1590/S0102-311X2013000600018.

25. Camargos MC, Gonzaga MR. Live longer and better? Estimates of healthy life expectancy in the Brazilian population. Cad Saude Publica. 2015;31(7): 1460-72. doi:10.1590/0102-311X00128914.

26. Sullivan DF. A single index of mortality and morbidity. HSMHA Health Rep. 1971;86(4):347-54. doi:10.2307/4594169.

27. Romero DE, Leite IC, Szwarcwald CL. Healthy life expectancy in Brazil: applying the Sullivan method. Cadernos de Saúde Pública. 2005;21(1 Suppl): 7-18. doi:10.1590/S0102-311X2005000700002.

28. Camargos MC, Rodrigues RN, Machado CJ. Healthy life expectancy to Brazilian elders, 2003. Cien Saude Colet. 2009;14(5):1903-9. doi:10.1590/ S1413-81232009000500032.

29. Victora CG, Barreto ML, Leal MC, Monteiro CA, Schmidt MI, Paim J, et al. Health conditions and health-policy innovations in Brazil: the way forward. Lancet. 2011;377(9782):2042-53. doi:10.1016/S0140-6736(11)60055-X

30. Instituto Brasileiro de Geografia e Estatística-IBGE. Diretoria de Pesquisas. Coordenação de Trabalho e Rendimento. Pesquisa Nacional de Saúde, 2013. Percepções do estado de saúde, estilos de vida, doenças crônicas. Brasil, Grandes Regiões e Unidades da Federação. Rio de Janeiro: IBGE; 2014. p. 181. ISBN 978-85-240-4334-5.

31. Szwarcwald CL, Malta DC, Pereira CA, Vieira ML, Conde WL, Souza Júnior PR, Damacena GN, Azevedo LO, Azevedo e Silva G, Theme Filha MM, Lopes Cde S, Romero DE, Almeida Wda S, Monteiro CA. National Health Survey in Brazil: design and methodology of application. Cien Saude Colet. 2014;19(2): 333-42. Portuguese.

32. Souza Júnior PRB, Freitas MPS, Antonaci GA, Szwarcwald CL. Sampling design of the National Health Survey 2013. Epidemiol Serv Saúde. 2015; 24(2):207-16. doi:10.5123/S1679-49742015000200003.

33. Belon AP, Lima MG, Barros MB. Gender differences in healthy life expectancy among Brazilian elderly. Health Qual Life Outcomes. 2014;12:88. doi:10.1186/1477-7525-12-88

34. IBGE-Brazilian Institute of Geography and Statistics. Complete mortality table for Brazil-2013. Brief mortality from the periods 2012-2013 and 1980-2013. Research Board. Rio de Janeiro: Population Coordination and Social Indicators; 2014

35. ABEP-Brazilian Association of Survey Firms. Brazilian Economic Classification Criteria/2013. Available in: http://www.abep.org/criterio-brasil.

36. Buss PM, Carvalho Al. Development of health promotion in Brazil in the last twenty years (1988-2008). Cien Saude Colet. 2009;14(6):2305-16. doi:10. 1590/S1413-81232009000600039.

37. Blank N, Diderichsen F. The prediction of different experiences of longterm illness: a longitudinal approach in Sweden. J Epidemiol Community Health. 1996;50(2):156-61. doi:10.1136/jech.50.2.156.

38. Silva ZP, Ribeiro MC, Barata RB, Almeida MF. Socio-demographic profile and utilization patterns of the public healthcare system (SUS), 2003-2008. Cien Saude Colet. 2011;16(9):3807-16. doi:10.1590/S141381232011001000016.

39. Collins B. Using a survey to estimate health expectancy and quality-adjusted life expectancy to assess inequalities in health and quality of life. Value Health. 2013;16(4):599-603. doi:10.1016/j.jval.2013.01.004.

40. Muhajarine $N$, Labonte R, Winquist BD. The Canadian Index of Wellbeing: key findings from the healthy populations domain. Can J Public Health. 2012;103(5):e342-7. 
41. Young Y, Boyd CM, Guralnik JM, Fried LP. Does self-reported function correspond to objective measures of functional impairment? J Am Med Dir Assoc. 2010;11(9):645-53. doi:10.1016/j.jamda.2009.12.084.

42. Vasconcellos MT, Silva PLN, Szwarcwald CL. Sampling design for the World Health Survey in Brazil. Cad Saude Publica. 2005;21(1 Suppl):89-99. doi:10. 1590/S0102-311X2005000700010.

43. Szwarcwald CL, Damacena GN, Souza Júnior PR, Almeida WS, Lima LT, Malta DC, et al. Determinants of self-rated health and the influence of healthy behaviors: results from the National Health Survey, 2013. Rev Bras Epidemiol. 2015;18(2 Suppl):33-44. doi:10.1590/19805497201500060004

44. Macinko J, Lima-Costa MF. Horizontal equity in health care utilization in Brazil, 1998-2008. Int J Equity Health. 2012;11:33. do:10.1186/1475-9276-11-33.

45. Pavão AL, Werneck GL, Campos MR. Self-rated health and the association with social and demographic factors, health behavior, and morbidity: a national health survey. Cad Saude Publica. 2013;29(4):723-34. doi:10.1590/ S0102-311X2013000400010.

46. Soares GP, Brum JD, Oliveira GM, Klein CH. Souza e Silva NA. Evolution of socioeconomic indicators and cardiovascular mortality in three Brazilian states. Arq Bras Cardiol. 2013;100(2):147-56. doi:10.5935/abc.20130028.

47. Guanais FC. The combined effects of the expansion of primary health care and conditional cash transfers on infant mortality in Brazil, 1998-2010. Am J Public Health. 2013;103(11):2000-6. doi:10.2105/AJPH.2013.301452.

48. Mújica OJ, Vázquez E, Duarte EC, Cortez-Escalante JJ, Molina J, Silva Junior JB. Socioeconomic inequalities and mortality trends in BRICS, 1990-2010. Bull World Health Organ. 2014:92(6):405-12. doi:10.2471/BLT.13.127977.

49. Kim Jl, Kim G. Social Structural Influences on Healthy Aging: CommunityLevel Socioeconomic Conditions and Survival Probability of Becoming a Centenarian for Those Aged 65 to 69 in South Korea. Int J Aging Hum Dev. 2015;81(4):241-59. doi:10.1177/0091415015623550.

50. Szwarcwald CL, Mota JC, Damacena GN, Pereira TG. Health inequalities in Rio de Janeiro, Brazil: lower healthy life expectancy in socioeconomically disadvantaged areas. Am J Public Health. 2011;101(3):517-23. doi:10.2105/AJPH.2010.195453.

51. Chang M, Molla MT, Truman BI, Athar H, Moonesinghe R, Yoon PW. Differences in healthy life expectancy for the US population by sex, race/ ethnicity and geographic region: 2008. J Public Health. 2015;37(3):470-9. doi:10.1093/pubmed/fdu059.

52. Mäki N, Martikainen P, Eikemo T, Menvielle G, Lundberg O, Ostergren O, et al. Educational differences in disability-free life expectancy: a comparative study of long-standing activity limitation in eight European countries. Soc Sci Med. 2013;94:1-8. doi:10.1016/j.socscimed.2013.06.009.

53. Newton JN, Briggs AD, Murray CJ, Dicker D, Foreman KJ, Wang H, et al. Changes in health in England, with analysis by English regions and areas of deprivation, 1990-2013: a systematic analysis for the Global Burden of Disease Study 2013. Lancet. 2015;386(10010):2257-74. doi:10.1016/501406736(15)00195-6.

54. Kim Jl, Kim G, Kim Jl, Kim G. Factors affecting the survival probability of becoming a centenarian for those aged 70 , based on the human mortality database: income, health expenditure, telephone, and sanitation. BMC Geriatr. 2014:14:113. doi:10.1186/1471-2318-14-113.

55. Love-Koh J, Asaria M, Cookson R, Griffin S. The Social Distribution of Health: Estimating Quality-Adjusted Life Expectancy in England. Value Health. 2015; 18(5):655-62. doi:10.1016/j.jval.2015.03.1784.

56. Fouweather T, Gillies C, Wohland P, Oyen HV, Nusselder W, Robine JM, et al. Comparison of socio-economic indicators explaining inequalities in Healthy Life Years at age 50 in Europe: 2005 and 2010. Eur J Public Health. 2015; 25(6):978-83. doi:10.1093/eurpub/ckv070.

\section{Submit your next manuscript to BioMed Central and we will help you at every step:}

- We accept pre-submission inquiries

- Our selector tool helps you to find the most relevant journal

- We provide round the clock customer support

- Convenient online submission

- Thorough peer review

- Inclusion in PubMed and all major indexing services

- Maximum visibility for your research

Submit your manuscript at www.biomedcentral.com/submit
Biomed Central 